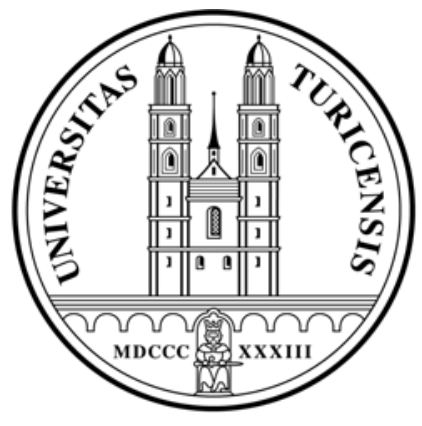

Institute for Empirical Research in Economics

University of Zurich

Working Paper Series

ISSN 1424-0459

Working Paper No. 340

Consumption growth, uncovered equity parity and the cross-section of returns on foreign currencies

Thomas Nitschka

November 2007 


\title{
Consumption growth, uncovered equity parity and the cross-section of returns on foreign currencies
}

\author{
Thomas Nitschka\#* \\ Institute for Empirical Research in Economics, University of Zurich
}

\begin{abstract}
Lagged foreign stock returns in excess of the U.S. stock market return are informative about quarterly exchange rate movements. A past high foreign stock return relative to the U.S. signals a foreign currency depreciation and hence low returns on the foreign currency. Conditional on stock return differentials, the consumption-based CAPM (CCAPM) explains the cross-sectional dispersion in U.S. dollar exchange rates. The CCAPM captures more than 40 percent of the variation in foreign currency returns scaled with the respective stock return differential on a country-by-country basis.
\end{abstract}

JEL classification: F31, G12

Keywords: consumption-based CAPM, foreign currency return, uncovered equity parity

\footnotetext{
\# Former versions of this paper circulated under the title "Consumption growth, uncovered equity parity and the cross-section of risk premia on foreign currencies". This paper constitutes chapter three of my Ph.D. thesis entitled "An asset pricing view on international financial integration". I would like to thank my supervisor Mathias Hoffmann for helpful remarks and suggestions. Additionally, I substantially benefited from discussions with Torsten Ehlers, Victoria Galsband, Iryna Shcherbakova and participants in the CFS Summer School on Empirical Macroeconomic Modelling 2006, the $13^{\text {th }}$ Annual Meeting of the German Finance Association and the $10^{\text {th }}$ Conference of the Swiss Society for Financial Market Research. Substantial parts of the research conducted in this paper are funded by the Deutsche Forschungsgemeinschaft through SFB 475, project B6: International Allocation of Risk. Any errors and omissions are my own.

*E-mail: thomas.nitschka@iew.uzh.ch
} 


\section{Introduction}

At the end of August 2006 the U.S. dollar has appreciated against the British Pound by 1.8 percent and at the same time depreciated against the Swiss Franc by 0.12 percent compared to July 2006. Why are there such differences in the change of the U.S. dollar exchange rates? We know since Mussa (1979) that exchange rates essentially behave like asset prices. Hence, exchange rate changes can be interpreted as returns on holding foreign currency and basic asset pricing theory should therefore apply to reconcile their cross-sectional differences. This paper shows that the consumption-based capital asset pricing model (CCAPM) canonized in Breeden (1979) and Breeden et al. (1989) explains up to 50 percent of the cross-sectional variation in quarterly returns on foreign currencies in the post Bretton-Woods period. This finding hinges on the use of stock market return differentials as conditioning instrument and is obtained from the perspective of a U.S. investor for U.S. dollar exchange rates of a set of 15 developed countries.

Since the covariation of exchange rate changes with consumption growth should be the main determinant of excess returns on foreign bonds, this paper is heavily influenced by the finding of Lustig and Verdelhan (2006) that consumption growth risk is priced in risk premia on foreign currencies. They show that various versions of the CCAPM do not only allow to explain the cross-section of domestic stock returns (Lettau and Ludvigson, 2001; Parker and Julliard, 2005; Yogo, 2006) but also of currency excess returns, i.e. the excess return on investment in foreign bonds. Key to success is the formation of annually rebalanced currency portfolios for a wide cross-section of countries sorted with respect to interest rate differentials. Lustig and Verdelhan present evidence that consumption-based models capture the crosssection of average excess returns on these currency portfolios, especially the model proposed by Yogo (2006). Market return based models, such as the Sharpe (1964) and Lintner (1965) 
CAPM or the Fama and French three-factor model (Fama and French, 1993), perform poorly in this respect.

The main findings of Lustig and Verdelhan suggest that the empirical failure of the uncovered interest rate parity condition (UIP) reflects basic asset pricing theory. Currencies from countries with high interest rates relative to the U.S. are perceived as relatively risky asset by the U.S. investor. Hence, those currencies have to offer relatively high returns, i.e. the foreign currency has to appreciate, while UIP predicts a foreign currency depreciation.

So, the use of interest rate differentials as instrumental variable should be helpful to reconcile cross-sectional differences in U.S. dollar exchange rate changes. In addition, a recent strand of literature emphasizes the tight link between cross-border capital flows, relative stock market returns and exchange rate changes among developed economies. This literature, briefly summarized in the subsequence, conveys the notion of an uncovered equity return parity condition (UEP).

Capital flows between stock markets have strongly increased in the past two decades (Tesar and Werner, 1995) and have gained considerable importance for exchange rates. Siourounis (2004) shows that flows between equity markets seem to be main the driving force for exchange rate movements among the five major currencies while the importance of bond flows seems to be negligible when both kinds of flows are considered simultaneously.

Based on a model with incomplete financial markets, Hau and Rey (2006) argue that portfolio rebalancing considerations lead to capital flows between equity markets that contemporaneously affect exchange rates. Investment into foreign equity exposes the investor to both equity return and currency return risk. Since capital markets are incomplete, exchange rate risk cannot be hedged. A higher foreign stock market return in local currency compared to the home stock market biases the investor's portfolio return to foreign stocks and exposes her to a higher currency risk. If this risk exposure is high enough, it is optimal for the investor to rebalance her stock portfolio and sell foreign stocks when they offer higher returns than the 
home stock market. Portfolio rebalancing thus creates flows between stock markets and hence exchange rate movements in the way observed in the data, i.e. high stock returns relative to the home country are associated with a foreign currency depreciation (Brooks et al., 2001; Hau and Rey, 2004).

Cappiello and De Santis (2005) argue that an arbitrage relation between expected returns on exchange rates and expected returns on stock markets implies UEP. Taking account of country-specific risk premia on stocks they find stock return differentials to be good predictors of the sign of expected exchange rate changes in- and out-of-sample. This latter result could be driven by the fact that the response of exchange rates to shocks in relative stock market returns persists one or two periods after the shock has occurred (Hau and Rey, 2004).

I exploit these findings and use lagged interest rate together with lagged stock return differentials as characteristics to form portfolios of currencies for the developed countries that are taken into consideration by Lustig and Verdelhan (2006). Relative stock returns and interest rate differentials are treated as instrumental variables for expected exchange rate changes. We know since Meese and Rogoff (1983) that our ability to forecast exchange rate changes is limited. ${ }^{1}$ The best we can do in this setting is to use previous period's interest rate differentials as suggested by UIP or, as I argue in this paper, employ lagged stock return differentials. The sorting of currencies into portfolios serves to ensure that there are large spreads in currency returns at quarterly frequencies. The portfolio formation in Lustig and Verdelhan (2006) for annual excess returns on foreign bonds has the same purpose.

I find that the simple CCAPM explains roughly 50 percent of the cross-sectional dispersion in average, quarterly returns on currency portfolios sorted by interest rate and stock return differentials. The estimated price of consumption growth risk is about two percentage points

\footnotetext{
${ }^{1}$ Mark (1995) and Hoffmann and MacDonald (2006) show that fundamentals (relative liquidities or real interest rate differentials for real exchange rates) capture the time series variation in nominal and real exchange rate changes in the long-run.
} 
per annum and we cannot reject the hypothesis that all pricing errors are zero. The portfolio characteristics suggest that both interest rate differentials and stock return differentials provide information about future exchange rate changes.

Moreover, evidence presented in this paper leaves the impression that -- judged by their sensitivity to consumption growth conditional on time variation in relative stock returns -currencies from countries with high past stock returns seem to be a less risky investment than their counterparts from past low stock return differential countries. This finding thus provides an additional rationale for using stock return differentials as instrumental variable in order to reconcile the cross-section of exchange rate changes.

Finally, I follow Cochrane (1996) and assess the conditional implications of the CCAPM by considering currency returns scaled with the respective stock return differential as test assets on a country-by-country basis. The conditional estimate of the price of consumption growth risk is statistically significantly different from zero and close to the values presented by Lustig and Verdelhan (2006). Furthermore, the fit of the CCAPM is about as well as in the case of currency portfolios. This latter result conveys the notion that prior portfolio formation does not seem to be necessary to explain the cross-section of returns on foreign currencies in a consumption-based asset pricing framework in a sample of developed countries.

The remainder of the paper is organized as follows. Section two describes the theoretical asset pricing framework while section three focuses on the empirical evidence for currency portfolios. In section four, I assess empirically the relation between stock return differentials, individual foreign currency returns and U.S. consumption growth. Section five reports the performance of the CCAPM when confronted with managed returns on foreign currencies. Section six concludes. 


\section{The CCAPM and returns on foreign currencies}

The first-order conditions of an investor's utility maximization problem give the basic consumption-based asset pricing equation

$$
P_{t}^{i}=E_{t}\left[\beta \frac{u^{\prime}\left(C_{t+1}\right)}{u^{\prime}\left(C_{t}\right)} X_{t+1}^{i}\right]
$$

with $P_{t}^{i}$ the price of asset $i$ and $X_{t+1}^{i}$ the corresponding payoff. $E_{t}$ is the expectation operator conditional on time $\mathrm{t}$ information, $\beta$ is the subjective discount factor and $u^{\prime}(C)$ denotes the first derivative of the utility function $u(C) . C_{t}$ represents consumption at time t.

Equivalently, gross returns, $\frac{X_{t+1}^{i}}{P_{t}^{i}}$, obey

$$
1=E_{t}\left(M_{t+1} R_{t+1}^{i}\right)
$$

with $M_{t+1} \equiv \beta \frac{u^{\prime}\left(C_{t+1}\right)}{u^{\prime}\left(C_{t}\right)}$ the stochastic discount factor and $R_{t+1}^{i}$ the gross return on asset or portfolio $i$. In words, any asset return should be discounted with the same stochastic discount factor (SDF) which is directly related to the intertemporal marginal rate of substitution of consumption.

We know since Mussa (1979) that exchange rates essentially behave like asset prices. I thus interpret a change in exchange rates as return on holding foreign currency. The focal point of this chapter is pure currency risk and not excess returns that accrue from the investment in e.g. foreign bonds as in Bekaert and Hodrick (1992) or Lustig and Verdelhan (2006).

Hence, equation (2) becomes

$$
1=E_{t}\left(M_{t+1} \Delta s_{t+1}^{i}\right)
$$

where $\Delta s_{t+1}^{i}$ represents a change in the log exchange rate defined as foreign currency $i$ over U.S. dollar. From the perspective of a U.S. investor, a foreign currency depreciation 
corresponds to a low or negative return on the foreign currency while a foreign currency appreciation implies a high or positive return.

I assume that the representative investor maximizes a power utility function. The first-order conditions imply

$$
M_{t+1}=\beta\left(\frac{C_{t+1}}{C_{t}}\right)^{-\gamma}
$$

where $\gamma$ represents the coefficient of relative risk aversion. A log-linear version of $M_{t+1}$ obeys

$$
m_{t+1}=\alpha-b_{\Delta c} \Delta c_{t+1}
$$

with $\alpha=\log (\beta)$ and $b_{\Delta c}=\gamma$.

Hence, equation (3) reduces to

$$
0=E_{t}\left(m_{t+1} \Delta s_{t+1}\right)
$$

Since consumption has been deflated, I define the nominal U.S. dollar exchange rate deflated with realized U.S. inflation as return on foreign currency, i.e.

$$
r_{t+1}^{i}=\Delta s_{t+1}^{i}-\pi_{t+1}
$$

with $r_{t+1}^{i}$ the deflated return on currency $i$ and $\pi_{t+1}$ realized U.S. inflation, such that equation (3) becomes

$$
0=E_{t}\left(m_{t+1} r_{t+1}^{i}\right)
$$

In the empirical part of this paper, I regard either returns on portfolios of currencies or currency returns scaled with an instrumental variable. Hence, I basically examine

$$
0=E\left(m_{t+1} z_{t} r_{t+1}^{i}\right)
$$

under the assumption that the instrument (or portfolio characteristic) $z$ observed at time $\mathrm{t}$ contains sufficient information about the investor's information set concerning expected exchange rate changes realized in $t+1$. Then equation (9) can be interpreted as the pricing equation of a managed portfolio of foreign currency returns (Cochrane, 1996). Of course, $z$ could also be a vector of instruments. 
Note that scaling returns is not the same as scaling pricing factors. By estimating the CCAPM with scaled returns I basically examine the conditional implications of the unconditional CCAPM, whereas scaling the factors implies a conditional model which is fundamentally different way to accommodate conditioning information in an asset pricing model (see the discussion in Lettau and Ludvigson, 2001 or chapter eight in Cochrane (2005)).

\section{Currency portfolios}

Even though the implications of UIP do not hold in the data, interest rate differentials mirror expected exchange rate changes (Lustig and Verdelhan, 2006). Hau and Rey (2004) and Cappiello and De Santis (2005) suggest that stock return differentials are a good statistic for expected currency returns at quarterly or higher frequency. I take both of these findings into account and form portfolios of currencies with respect to one-quarter lagged interest rate and stock return differentials to ensure large spreads in currency returns. This sorting would be inappropriate if the two characteristics were highly correlated. However, the correlations between interest rate and stock return differentials vary between -0.24 and -0.02 .

The sample spans the period from 1974Q1 to 2005Q4 and takes the following countries under consideration: Australia, Austria, Belgium, Canada, Denmark, France, Germany, Greece, Ireland, Italy, Japan, Netherlands, New Zealand, Norway, Portugal, Spain, Sweden, Switzerland and the United Kingdom.

I obtain data on short-term interest rates from the IFS tape November 2006. Quarterly data on stock returns is calculated from end-of-period returns on the Morgan Stanley Capital International (MSCI) stock index of the respective countries in local currency. ${ }^{2}$ Quarterly currency returns are calculated from end-of-quarter MSCI stock returns in local currency at time $t$ and the respective stock returns in U.S.-dollars. Positive foreign currency returns are

\footnotetext{
${ }^{2}$ These stock indexes are freely available on www.mscibarra.com .
} 
thus associated with a depreciation of the U.S. dollar. Returns on foreign currencies are deflated with the change in the U.S. consumer price index (CPI) published in the IFS tape November 2006.

\subsection{Portfolio characteristics}

At first stage, I form three portfolios sorted by lagged interest rate differentials. The first portfolio consists of the $30 \%$ of countries with highest interest rate differentials, the second one of the $40 \%$ of countries with middle interest rate differential and portfolio three contains the remaining $30 \%$ of countries with lowest interest rate differential via-à-vis the U.S. Then I distinguish between high and low stock return differentials compared to the U.S. within the interest rate differential sorted portfolios, such that I obtain six portfolios which are rebalanced every quarter. ${ }^{3}$

Table 1 presents average excess returns and the Sharpe-ratio of all six portfolios. Note that portfolio P11 contains the countries with highest interest rate differential compared to the U.S. (the first "1") and among those the countries with high stock return differentials (the second "1"). Portfolio P12 consists of countries with highest interest rate differential relative to the U.S. and among those of the countries with low stock return differential. Accordingly, P32 is the portfolio of exchange rates from countries with lowest interest rate differential and relatively low stock returns.

The portfolio characteristics convey the notion that a) high interest rate currencies offer relatively high average returns and b) high foreign stock returns relative to the U.S. are associated with depreciating foreign currencies and hence negative or lower foreign currency returns than low stock return countries from the perspective of a U.S. investor. The clear exceptions are the middle interest rate portfolios, P21 and P22, for which high stock return differential currencies offer higher returns than countries with low stock returns compared to

\footnotetext{
${ }^{3}$ The number of six portfolios is chosen to make sure that each of the portfolios contains currencies from at least two countries over the whole sample period.
} 
the U.S. Nonetheless, the portfolio characteristics support Lustig and Verdelhan (2006) as well as Cappiello and De Santis (2005) and Hau and Rey (2004). They reflect the failure of uncovered interest rate parity and at the same time the presence of the persistent impact of stock return differential shocks on nominal exchange rate changes. High interest rates relative to the U.S. signal appreciating foreign currencies and hence high foreign currency returns for a U.S. investor. Past high foreign stock returns in excess of the U.S. stock market return reflect low returns on these currencies.

\subsection{Risk prices}

In order to receive a representation of equation (2) in terms of risk prices, I exploit $E(X Y)=E(X) E(Y)+\operatorname{cov}(X, Y)$, such that

$$
E_{t}\left(R_{t+1}^{i}\right)=\frac{1}{E_{t}\left(M_{t+1}\right)}+\left(\frac{\operatorname{cov}\left(R_{t+1}^{i}, M_{t+1}\right)}{\operatorname{var}\left(M_{t+1}\right)}\right)\left(-\frac{\operatorname{var}\left(M_{t+1}\right)}{E_{t}\left(M_{t+1}\right)}\right)
$$

which can be summarized to

$$
E_{t}\left(R_{t+1}^{i}\right)-R_{t}^{f}=\beta_{M}^{i} \lambda_{M}
$$

with $R_{t}^{f}=\frac{1}{E_{t}\left(M_{t+1}\right)}$, the risk-free rate, $\beta_{M}^{i}=\frac{\operatorname{cov}\left(R_{t+1}^{i}, M_{t+1}\right)}{\operatorname{var}\left(M_{t+1}\right)}$, the regression coefficient of excess return $i$ on the discount factor, representing the asset-specific quantity of systematic risk, and $\lambda_{M}=-\frac{\operatorname{var}\left(M_{t+1}\right)}{E_{t}\left(M_{t+1}\right)}$ interpreted as the price of risk.

As consumption growth is the only source of systematic risk in this setting, (11) collapses to

$$
E_{t}\left(R_{t+1}^{i}\right)-R_{t}^{f}=\beta_{\Delta c}^{i} \lambda_{\Delta c}
$$

in which $\lambda_{\Delta c}$ is the price of consumption growth risk and $\beta_{\Delta c}^{i}$ the asset-specific exposure to consumption growth risk. High currency excess returns should thus be associated with high consumption growth betas as $\lambda_{\Delta c}$ is the same for all assets. 
I use the Fama-MacBeth cross-sectional regression (Fama and MacBeth, 1973) to estimate the beta representation (12). The first stage of the Fama-MacBeth estimation is a time series regression of currency excess returns on consumption growth

$$
r_{t}^{e, i}=\mu+\beta_{\Delta c}^{i} \Delta c_{t}+\varepsilon_{t}^{i}
$$

The estimated betas measure the exposure of currency risk premia to consumption growth risk. In the second step of the Fama-MacBeth regression, I assess if differences in the exposure to consumption growth risk can account for differences in average excess returns on currencies. I thus run cross-sectional regressions at each point in time, i.e.

$$
r_{t}^{e, i}=\lambda_{0}+\lambda_{\Delta c} \hat{\beta}_{\Delta c}^{i}+v_{t}^{i}, \forall t
$$

allowing for an intercept $\lambda_{0}$.

Table 2 presents the results. The point estimates are reported in percentage points per quarter. T-statistics in parenthesis appear below the estimates and are corrected for the fact that the $\hat{\beta}_{\Delta c}^{i}$ are generated regressors (Shanken, 1992). The column $\mathrm{R}^{2}$ gives the cross-sectional $\mathrm{R}^{2}$ adjusted for the number of regressors as used in Campbell and Vuolteenaho (2004). ${ }^{4}$

The estimated price of consumption growth risk, $\lambda_{\Delta c}$, is statistically significantly different from zero. The price of 0.5 percentage points per quarter corroborates the annual price of consumption growth risk of approximately two percentage points p.a. estimated by Lustig and Verdelhan (2006). Judged by the $R^{2}$, the simple CCAPM explains about half of the crosssectional variation in average risk premia on currency portfolios.

Figure 1 plots mean realized excess returns on currency portfolios against their values predicted by the CCAPM to provide a visual impression of the fit of model. The CCAPM has difficulties to price the high stock return portfolios in the high and low interest rate differential bin while it does reasonably well for the other portfolios.

\footnotetext{
${ }^{4}$ The $\mathrm{R}^{2}$ is defined as $R^{2}=1-\frac{e^{\prime} e}{\left(\bar{R}^{e, i}-\sum_{j} \bar{R}^{e, i}\right)^{\prime}\left(\bar{R}^{e, i}-\sum_{j} \bar{R}^{e, i}\right)}$ where $\bar{R}$ denotes a time series average
} 


\subsection{Consumption growth betas}

The first stage of the Fama and MacBeth cross-sectional regression is useful to assess if the notion that high currency excess returns should be associated with high, positive consumption growth betas pertains in this setting. Table 3 reports the consumption growth betas of the six currency portfolio excess returns. Newey-West corrected t-statistics are in parenthesis (Newey and West, 1987). Figure 2 summarizes the results graphically.

If consumption growth betas were to explain the mean return on the respective currency portfolio exactly, then the points in figure 2 would line up perfectly. High consumption betas should be associated with high average excess returns. This is exactly the pattern that we observe in figure 2 with the exception of the portfolio consisting of countries with highest interest rate differential and among those with high stock return differential relative to the U.S. But apart from this outlier, figure 2 supports the findings of Lustig and Verdelhan (2006). High average returns on currencies can be rationalized by their consumption growth betas conditional on instrumental variables (here interest rate and stock return differentials). The currencies which are strongest positively related to U.S. consumption growth, and thus destabilize the U.S. investor's consumption path, have to compensate this riskiness with high average returns.

\subsection{GMM estimates}

The representation (9) naturally suggests to use pricing errors as moment conditions in the GMM framework of Hansen and Singleton (1982) to estimate the parameter $b_{\Delta c}$ and to judge the quality of the model on the basis of the restrictions on expected discounted returns imposed by equation (9). Remember that $b_{\Delta c}$ reflects the coefficient of relative risk aversion. An estimate of the risk aversion parameter will tell us at what cost the success of the CCAPM in capturing the cross-section of currency portfolio returns comes. Note, that GMM chooses 
the parameter $b_{\Delta c}$ to minimize the pricing errors, i.e. to make the CCAPM explain the crosssection of currency excess returns as well as possible.

In equation (7), I follow common practice and set $\alpha$ to unity to consider

$$
m_{t+1}=1-b_{\Delta c} \Delta c_{t+1}
$$

as specification of the stochastic discount factor. The moment conditions are

$$
g_{T}(b)=E_{T}\left(m_{t} \boldsymbol{R}_{t}\right)=E_{T}\left(\boldsymbol{R}_{t}\right)-E_{T}\left(\boldsymbol{R}_{t} \boldsymbol{f}_{t}{ }^{\prime}\right) b
$$

where $\boldsymbol{R}_{t}$ is the vector of returns on the six currency portfolios, $\boldsymbol{f}_{t}$ is a vector of pricing factors, here only consumption growth, and $E_{T}$ denotes a time series average.

In the first stage of the GMM estimation, I use the identity matrix as weighting matrix and in the second stage the optimal weighting matrix with $\mathrm{N}+1$ lags. $\mathrm{N}$ is the number of test assets. The GMM results reported in this paper remain qualitatively the same if I regard only firststage GMM estimates or if I let the number of lags in the second stage estimation vary around reasonable values.

Table 4 presents the estimate of $b_{\Delta c}$ with t-statistics in parenthesis, the price of consumption growth risk implied by the GMM estimate as well as the p-value of the test of overidentifying restrictions for the null that all pricing errors are jointly zero.

The estimate corroborates the well-known observation that the success of consumption-based models in explaining the cross-section of asset returns comes at the cost of implausibly high estimates of the risk aversion coefficient (Mark, 1985; Campbell and Cochrane, 1999; Yogo, 2006). However, the risk price of consumption growth implied by the GMM estimates is very close to the Fama-MacBeth regression estimates. Furthermore, we cannot reject the hypothesis of all pricing errors being zero at conventional confidence levels. The GMM results thus complement the estimation of risk prices and underscore that the CCAPM is able to capture the cross-sectional dispersion of risk premia on foreign currencies. 


\section{Stock return differentials, consumption growth and exchange rate changes: A country-by-country analysis}

So far I have argued that the evidence of exchange rate predictability by Cappiello and De Santis (2005) and the persistence of stock return differential shocks for exchange rate changes (Hau and Rey, 2004) qualify lagged foreign stock market returns in excess of the U.S. stock market as explanatory variable for exchange rate changes.

However, I find it useful to assess the relationship of currency returns with stock return differentials in combination with the implications from consumption based asset pricing. Currencies from countries with high past stock returns compared to the U.S. should depreciate against the U.S. dollar and thus offer low or even negative returns. Hence these currencies should have relatively low or negative consumption growth betas.

To test this conjecture, I run a regression of U.S. dollar exchange rates for the countries under consideration on U.S. consumption growth and control for time variation in relative stocks by interacting U.S. consumption growth with the respective one-quarter lagged stock return differential. The regression takes the following form

$$
\Delta s_{t+1}^{i}=\mu+\beta_{\Delta c} \Delta c_{t+1}+\beta_{\Delta c, r} \Delta c_{t+1}\left(s r_{t}^{i}-s r_{t}\right)+\varepsilon_{t+1}
$$

for U.S. dollar exchange rate changes of country $i$ where $s r_{t}^{i}-s r_{r}$ represents the stock market differential of country $i$ compared to the U.S. and $\Delta c_{t+1}$ denotes U.S. consumption growth. The point estimates as well as Newey-West corrected t-statistics are displayed in table 5 . Figure 3 visualizes the results. The upper panel presents the consumption growth betas, the lower panel shows the betas with respect to consumption growth interacted with lagged stock return differentials. 
The upper panel of figure 3 displays that returns on individual currencies line up with their consumption growth betas. High returns on currencies are associated with high consumption growth betas, whereas low currency returns seem to be the consequence of low covariances with consumption growth. This is exactly what is implied by a consumption-based asset pricing framework.

Furthermore, the lower panel of figure 3 provides support for the view that lagged stock return differentials are informative about exchange rate changes in the way as proposed by UEP. Conditioning consumption growth with stock return differentials leaves the impression that high returns on the foreign stock market relative to the U.S. are associated with a foreign currency depreciation and hence with low (negative) returns for a U.S. investor. ${ }^{5}$

For comparison, figure 4 gives a visual impression of the results from a regression using the corresponding interest rate differential as scaling variable. Table 6 displays the OLS estimates of the regression

$$
\Delta s_{t+1}^{i}=\mu+\beta_{\Delta c} \Delta c_{t+1}+\beta_{\Delta c, i} \Delta c_{t+1}\left(i_{t}^{i}-i_{t}\right)+\varepsilon_{t+1}
$$

where $i_{t}^{i}-i_{t}$ is the interest rate differential of country $i$ with the U.S. In analogy to the latter finding, high average currency returns should be associated with high consumption growth betas. Betas of the interacted consumption growth term should reflect that currencies from high interest rate countries promise high returns.

Evidence for the latter implication gleams through the lower panel of figure 4. But there does not seem to be a systematic relation between average currency returns and their consumption growth betas on a country-by-country basis conditional on time-variation in interest rate differentials.

\footnotetext{
${ }^{5}$ This observation is qualitatively unaffected by considering consumption growth scaled with interest rate differentials as additional regressor. Results are not reported but available upon request.
} 


\section{$5 \quad$ Managed excess returns on foreign currency}

Stock return differentials among developed countries are important in reconciling quarterly exchange rate changes. Returns on foreign currencies can be rationalized by their sensitivity to consumption growth once one takes time variation in stock return differentials into account. This finding conveys the notion that the conditional implications of the CCAPM for individual currency returns can be tested by regarding returns on foreign currencies scaled with their respective stock return differentials vis-à-vis the U.S. ${ }^{6}$ Stock return differentials then serve as conditioning instrument or signal, such that scaled currency returns can be interpreted as investment in an asset managed according to this signal (Cochrane, 1996).

Panel A of table 7 presents estimates from a Fama-MacBeth cross-sectional CCAPM regression performed on 15 quarterly currency returns scaled with the respective stock return differential relative to the U.S.

The estimated price of consumption growth risk is statistically significant and near the estimated value when returns on currency portfolios are considered. The cross-sectional $\mathrm{R}^{2}$ indicates that the CCAPM explains about 44 percent of the cross-sectional dispersion in scaled returns on foreign currencies. Note also that the $\mathrm{R}^{2}$ is close to the value obtained for currency portfolios

Panel B gives the corresponding GMM estimates. These results largely corroborate the previous results for currency portfolios and show that the CCAPM passes the test of overidentifying restrictions when confronted with scaled currency returns.

Figure 5 displays the pricing errors of the CCAPM. I present mean actual currency returns in percentage points per quarter (horizontal axis) compared with the returns predicted by the

\footnotetext{
${ }^{6}$ In order to maintain the scale of the moments of the currency returns, they are scaled with $1+\frac{s r_{t}^{i}-s r_{t}}{\sigma\left(s r_{t}^{i}-s r_{t}\right)}$ where $\sigma\left(s r_{t}^{i}-s r_{t}\right)$ is the standard deviation of the (demeaned) stock return differentials.
} 
model. The CCAPM seems to fit the data reasonably well also in terms of pricing errors. Figure 6 gives the scaled currency returns (horizontal axis) relative to their consumption growth betas (vertical axis). High currency returns are associated with high consumption growth betas and vice versa.

All in all, this evidence leaves the impression that, conditional on the respective stock market return differentials relative to the U.S., the CCAPM is not only able to explain the crosssectional variation in currency portfolio but also individual quarterly currency returns. This relation holds if the sample is restricted to countries for which uncovered equity parity holds. In such a setting prior formation of portfolios does not seem to be necessary in order to test the conditional implications of the CCAPM for returns on foreign currency.

\section{Summary}

The CCAPM prices average returns on currency portfolios, sorted with respect to lagged interest rate and stock return differentials. Evidence presented in this chapter suggests that lagged foreign stock returns in excess of the U.S. stock market return are informative about exchange rate movements. A past high foreign stock return relative to the U.S. signals a foreign currency appreciation and hence low returns on the foreign currency. Thus, the CCAPM also prices foreign currency returns scaled with the respective stock return differential on a country-by-country basis.

The main results thus complement recent evidence by Lustig and Verdelhan (2006) that highlight the ability of consumption-based models to explain returns on foreign assets, here returns on foreign currencies. Furthermore, this paper stresses the intimate relation between stock and foreign exchange markets as emphasized in Hau and Rey (2004, 2006). 


\section{References}

Bekaert, Geert and Robert J. Hodrick (1992), "Characterizing Predictable Components in Excess Returns on Equity and Foreign Exchange Markets”, Journal of Finance, 47, 467-509.

Breeden, Douglas T. (1979), "An intertemporal asset pricing model with stochastic consumption and investment opportunities", Journal of Financial Economics, 7, 265-296.

Breeden, Douglas T., Michael R. Gibbons and Robert H. Litzenberger (1989), "Empirical tests of the consumption-oriented CAPM”, Journal of Finance, 44, 231-262.

Brooks, Robin, Edison, Hali, Kumar, Manmohan and Torsten Slok (2001), "Exchange Rates and Capital Flows", IMF working paper WP/01/190.

Campbell, John Y. (1999), “Asset Prices, Consumption and the Business Cycle”, in John Taylor and Mark Woodford, eds., Handbook of Macroeconomics, Amsterdam: North Holland.

Campbell, John Y. and John H. Cochrane (1999), "By Force of Habit: A Consumption-Based Explanation of Aggregate Stock Market Behaviour", Journal of Political Economy, 107, 205251.

Cappiello, Lorenzo and Roberto A. De Santis (2005), "Explaining Exchange Rate Dynamics: The Uncovered Equity Return Parity Condition", ECB working paper 529.

Cochrane, John H. (1996), "A Cross-Sectional Test of an Investment-Based Asset Pricing Model", Journal of Political Economy, 104, 572-621.

Cochrane, John H. (2005), Asset Pricing, 2nd edition, Princeton University Press, Princeton and Oxford.

Engel, Charles (1996), "The forward discount anomaly and the risk premium: A survey of recent evidence", Journal of Empirical Finance, 3, 123-192.

Fama, Eugene F. and James D. MacBeth (1973), "Risk, Return and Equilibrium: Empirical Tests", Journal of Political Economy, 81, 607-631.

Fama, Eugene F. and Kenneth R. French (1993), "Common risk factors in the returns on stocks and bonds", Journal of Financial Economics, 33, 3-56.

Hansen, Lars Peter and Kenneth J. Singleton (1982), "Generalized Instrumental Variables Estimation of Nonlinear Rational Expetations Models", Econometrica, 50, 1269-1288.

Hau, Harald and Helene Rey (2004), "Can Portfolio Rebalancing Explain The Dynamics Of Equity Returns And Exchange Rates?", American Economic Review P\&P, 94, 126-133.

Hau, Harald and Helene Rey (2006), "Exchange Rates, Equity Prices and Capital Flows", Review of Financial Studies, 19, 273-317. 
Lettau, Martin and Sydney Ludvigson (2001), "Resurrecting the (C)CAPM: A CrossSectional Test When Risk Premia Are Time-Varying", Journal of Political Economy, 109, 1238-1287.

Lintner, John (1965), "The valuation of risk assets and the selection of risky investments in stock portfolios and capital budgets", Review of Economics and Statistics ,47, 13-37.

Lustig, Hanno and Adrien Verdelhan (2006), "The Cross-Section Of Foreign Currency Risk Premia And Consumption Growth Risk", forthcoming American Economic Review

Mark, Nelson C. (1985), "On Time Varying Risk Premia in the Foreign Exchange Market", Journal of Monetary Economics, 16, 2-18.

Meese, Richard.A. and Kenneth Rogoff (1983), "Empirical Exchange Rate Models of the Seventies: Do they fit Out Of Sample?”, Journal of International Economics 14, 3-24.

Mussa, Michael (1979), "Empirical Regularities in the Behaviour of Exchange Rates and Theories of the Foreign Exchange Rates", in K.Brunner and A. Meltzer (eds.) Carnegie Rochester Conference Series 11, 9-58.

Newey, Whitney K. and Kenneth D. West (1987), "A simple, positive semidefinite, heteroskedasticity and autocorrelation consistent covariance matrix", Econometrica, 55, 703708.

Parker, Jonathan A. and Christian Julliard (2005), "Consumption Risk and the Cross Section of Expected Returns", Journal of Political Economy, 113, 185-222.

Shanken, Jay (1992), "On the Estimation of Beta-Pricing Models", Review of Financial Studies, 5, 1-33.

Sharpe, William F. (1964), "Capital asset prices: A theory of market equilibrium under conditions of risk", Journal of Finance, 19, 425-442.

Siourounis, Gregorios (2004), "Capital Flows and Exchange Rates: An Empirical Analysis", working paper London Business School.

Tesar, Linda L. and Ingrid M. Werner (1995), "Home Bias and High Turnover", Journal of International Money and Finance, 14, 467-492.

Yogo, Motohiro (2006), "A Consumption-Based Explanation of Expected Stock Returns", Journal of Finance 61(2), pp. 539-580. 


\section{Tables}

Table 1: Portfolio characteristics

\begin{tabular}{ccccccc}
\hline \hline & $\mathrm{P} 11$ & $\mathrm{P} 12$ & $\mathrm{P} 21$ & $\mathrm{P} 22$ & $\mathrm{P} 31$ & $\mathrm{P} 32$ \\
$\begin{array}{c}\text { Mean excess } \\
\text { return }\end{array}$ & 0.8152 & 1.3837 & 0.0303 & -1.8329 & -3.3263 & -1.8733 \\
$\begin{array}{c}\text { Sharpe-ratio } \\
\text { Shar }\end{array}$ & 0.0387 & 0.0663 & 0.0015 & -0.0860 & -0.1491 & -0.0771
\end{tabular}

Notes: This table presents annualized average returns and the corresponding sharpe ratio of six currency portfolios that are rebalanced quarterly. Currencies are first sorted into portfolios according to their interest differential vis-à-vis the U.S. In a second step I distinguish between high and low stock return differentials compared to the U.S among the interest rate sorted portfolios. Portfolio P11 contains the countries with highest interest rates and among those with highest stock returns relative to the U.S. Portfolio P32 hence consists of countries with lowest interest rate and among those with low stock return differentials. The Sharpe-ratio is the ratio of mean return and standard deviation of the return. The sample period covers the time from first quarter 1974 to second quarter 2003 and comprises data on 20 developed countries.

Table 2: Risk price estimates (currency portfolios)

\begin{tabular}{cccc}
\hline \hline & $\lambda_{0}$ & \multicolumn{1}{c}{$\lambda_{\Delta c}$} & $R^{2}$ \\
\hline CCAPM & -1.2238 & 0.5016 & 0.49 \\
& $(-1.7307)$ & $(2.3216)$ &
\end{tabular}

Notes: This table reports the risk price of consumption growth (in percentage points per quarter) from a cross-sectional Fama-MacBeth CCAPM regression of the form:

$$
r_{t}^{e, i}=\lambda_{0}+\lambda_{\Delta c} \hat{\beta}_{\Delta c}^{i}+\varepsilon_{t}^{i}, \forall t
$$

in which $r_{t}^{e, i}$ denotes excess returns on currency portfolio $i$. The betas are obtained from multiple time-series regressions of the currency portfolio risk premia on consumption growth. The sample period runs from first quarter 1974 to second quarter 2003.

As the betas are generated regressors, t-statistics that are corrected for this errors-in-variables issue (Shanken, 1992) are presented in parenthesis. $\mathrm{R}^{2}$ denotes the adjusted cross-sectional $\mathrm{R}^{2}$. 
Table 3: Consumption growth betas

\begin{tabular}{lcll}
\hline \hline & Mean return & constant & \multicolumn{1}{c}{$\beta_{\Delta c}$} \\
\hline P11 & 0.2038 & -0.5309 & 1.5626 \\
& & $(-0.5764)$ & $(1.2138)$ \\
& 0.3459 & -1.0721 & 3.0161 \\
P21 & & $(-1.4066)$ & $(2.5239)$ \\
& 0.0076 & -1.0649 & 2.2811 \\
P22 & & $(-1.3057)$ & $(1.9377)$ \\
& -0.4582 & -1.4073 & 2.0186 \\
P31 & & $(-1.5554)$ & $(1.5002)$ \\
& -0.8316 & -1.5468 & 1.5212 \\
P32 & & $(-1.8714)$ & $(1.1570)$ \\
& -0.4683 & -1.3353 & 1.8441 \\
& & $(-1.5318)$ & $(1.3322)$
\end{tabular}

Notes: This table presents OLS estimates from the first stage of the FamaMacBeth regression of currency portfolio returns on consumption growth. The estimate equation takes the following form :

$$
r_{t}^{e, i}=\mu^{i}+\beta_{\Delta c}^{i} \Delta \log c_{t}+\varepsilon_{t}^{i}
$$

T-statistics in parenthesis are computed using Newey-West corrected standard errors with $\mathrm{K}+1$ lags where $\mathrm{K}$ is the number of regressors. The results are visualized in figure 2 .

Table 4: GMM estimates (currency portfolios)

\begin{tabular}{cccc}
\hline \hline & $b_{\Delta c}$ & implied $\lambda_{\Delta c}$ & J-Test (p-value) \\
\hline CCAPM & 134.2526 & 0.5128 & 0.46
\end{tabular}

Notes: This table reports estimates of the coefficient of relative risk aversion from a two-stage GMM estimation of linear versions of the CCAPM. The stochastic discount factor is specified as $m_{t+1}=1-b_{\Delta c} \Delta \log c_{t+1}$.

I use the identity matrix in the first stage and the optimal weighting matrix in the second stage applying a lag length of $\mathrm{N}+1$, where $\mathrm{N}$ is the number of test assets. The implied risk prices, $\lambda_{\Delta c}$, are calculated from $\lambda=E\left(f f^{\prime}\right) b$. The J-Test is a $\chi^{2}$-test of the null that all pricing errors are jointly zero with degrees of freedom equal to number of moments less number of parameters. 
Table 5: exchange rate changes and (conditional) consumption growth betas (stock return differentials)

\begin{tabular}{|c|c|c|c|}
\hline Country & constant & $\overline{\beta_{\Delta c}^{i}}$ & $\overline{\beta_{\Delta c, i}^{i}}$ \\
\hline \multirow[t]{2}{*}{ AUS } & 0.0513 & 0.0539 & -0.0336 \\
\hline & $(0.7777)$ & $(0.6104)$ & $(-1.9887)$ \\
\hline \multirow[t]{2}{*}{ AUT } & 0.0491 & 0.3278 & 0.0088 \\
\hline & $(0.4839)$ & (1.6828) & (0.3993) \\
\hline \multirow[t]{2}{*}{ BEL } & 0.0237 & -0.0651 & -0.0395 \\
\hline & $(0.2154)$ & $(-0.4125)$ & $(-1.7650)$ \\
\hline \multirow[t]{2}{*}{ CND } & 0.0006 & -0.0064 & -0.0193 \\
\hline & $(0.0214)$ & $(-0.1578)$ & $(-3.2660)$ \\
\hline \multirow[t]{2}{*}{ DK } & -0.0561 & 0.0053 & -0.0487 \\
\hline & $(-0.5710)$ & $(0.0394)$ & $(-3.3499)$ \\
\hline \multirow[t]{2}{*}{ FRA } & 0.0935 & -0.0866 & -0.0334 \\
\hline & (1.3003) & $(-0.9155)$ & $(-2.8843)$ \\
\hline \multirow[t]{2}{*}{ GER } & 0.0717 & 0.0791 & -0.0283 \\
\hline & $(0.8898)$ & $(0.6461)$ & $(-1.7528)$ \\
\hline \multirow[t]{2}{*}{ GRE } & -0.6232 & 2.1799 & -0.1294 \\
\hline & $(-0.4175)$ & $(0.7724)$ & $(-1.5658)$ \\
\hline \multirow[t]{2}{*}{ IRL } & -2.0808 & 2.2937 & -0.1164 \\
\hline & $(-1.6972)$ & $(0.9684)$ & $(-0.6551)$ \\
\hline \multirow[t]{2}{*}{ ITA } & -0.0329 & 0.0553 & -0.0512 \\
\hline & $(-0.2379)$ & $(0.2892)$ & $(-2.4935)$ \\
\hline \multirow[t]{2}{*}{ JPN } & -0.0359 & -0.0209 & -0.0193 \\
\hline & $(-0.5153)$ & $(-0.1626)$ & $(-1.3118)$ \\
\hline \multirow[t]{2}{*}{ NL } & 0.0443 & -0.1149 & -0.0313 \\
\hline & $(0.8548)$ & $(-1.3392)$ & $(-2.4309)$ \\
\hline \multirow[t]{2}{*}{ NZ } & -1.0426 & -0.8286 & -0.2933 \\
\hline & $(-1.1223)$ & $(-0.5237)$ & $(-2.8837)$ \\
\hline \multirow[t]{2}{*}{ NOR } & 0.2015 & -0.2189 & -0.0491 \\
\hline & (1.3130) & $(-0.9193)$ & $(-2.4910)$ \\
\hline \multirow[t]{2}{*}{ POR } & -1.8586 & 3.0567 & -0.0832 \\
\hline & $(-1.4522)$ & $(1.2342)$ & $(-0.8198)$ \\
\hline \multirow[t]{2}{*}{ ESP } & -0.0180 & 0.1327 & -0.0528 \\
\hline & $(-0.2499)$ & (0.8319) & $(-2.5481)$ \\
\hline \multirow[t]{2}{*}{ SWE } & 0.0674 & 0.0289 & 0.0036 \\
\hline & (1.0273) & $(0.3450)$ & $(0.5094)$ \\
\hline \multirow[t]{2}{*}{$\mathrm{CH}$} & 0.0232 & 0.0650 & -0.0118 \\
\hline & $(0.3388)$ & (0.5558) & $(-0.8355)$ \\
\hline \multirow[t]{2}{*}{ UK } & -0.0291 & 0.0294 & -0.0274 \\
\hline & $(-1.4247)$ & $(0.7816)$ & $(-3.7866)$ \\
\hline
\end{tabular}


Notes: This table presents results from regressions of the form

$$
\Delta s_{t+1}^{i}=\mu+\beta_{\Delta c} \Delta c_{t+1}+\beta_{\Delta c, r} \Delta c_{t+1}\left(r_{t}^{i}-r_{t}\right)+\varepsilon_{t+1}
$$

with $\Delta s_{t+1}^{i}$ the U.S. dollar exchange rate change of country $i, \Delta c_{t+1} \log$ U.S. consumption growth, $r_{t}^{i}-r_{t}$ the stock return differential of country $i$ relative to the U.S. 
Table 6: exchange rate changes and (conditional) consumption growth betas (interest rate differentials)

\begin{tabular}{|c|c|c|c|}
\hline country & constant & $\overline{\beta_{\Delta c}^{i}}$ & $\overline{\beta_{\Delta c, i}^{i}}$ \\
\hline \multirow[t]{2}{*}{ AUS } & 0.0565 & 0.0225 & 0.0282 \\
\hline & $(0.8616)$ & $(0.2610)$ & $(0.3282)$ \\
\hline \multirow[t]{2}{*}{ AUT } & 0.0229 & 0.4190 & 0.3940 \\
\hline & $(0.2408)$ & $(2.0242)$ & (1.7483) \\
\hline \multirow[t]{2}{*}{ BEL } & -0.0178 & -0.0127 & 0.0609 \\
\hline & $(-0.1688)$ & $(-0.0795)$ & $(0.4406)$ \\
\hline \multirow[t]{2}{*}{ CND } & 0.0139 & -0.0653 & 0.0956 \\
\hline & $(0.5106)$ & $(-1.2810)$ & (1.5505) \\
\hline \multirow[t]{2}{*}{ DK } & -0.0582 & -0.0177 & 0.1389 \\
\hline & $(-0.6491)$ & $(-0.1189)$ & $(0.4754)$ \\
\hline \multirow[t]{2}{*}{ FRA } & 0.0799 & -0.2486 & 0.1827 \\
\hline & (1.2028) & $(-2.0924)$ & (2.5243) \\
\hline \multirow[t]{2}{*}{ GER } & 0.0066 & 0.3356 & 0.4453 \\
\hline & $(0.0850)$ & $(2.0751)$ & (2.2229) \\
\hline \multirow[t]{2}{*}{ GRE } & -0.5786 & -1.0993 & 1.3298 \\
\hline & $(-0.4406)$ & $(-0.3623)$ & (1.2433) \\
\hline \multirow[t]{2}{*}{ IRL } & -2.1642 & 1.7272 & 2.1222 \\
\hline & $(-1.8329)$ & $(0.6624)$ & (1.0497) \\
\hline \multirow[t]{2}{*}{ ITA } & -0.0163 & -0.3691 & 0.2949 \\
\hline & $(-0.1347)$ & $(-1.7835)$ & (1.6551) \\
\hline \multirow[t]{2}{*}{ JPN } & -0.0312 & -0.0334 & -0.0690 \\
\hline & $(-0.4358)$ & $(-0.2542)$ & $(-0.6917)$ \\
\hline \multirow[t]{2}{*}{ NL } & 0.0393 & -0.1061 & 0.1022 \\
\hline & $(0.6818)$ & $(-0.9679)$ & $(0.8191)$ \\
\hline \multirow[t]{2}{*}{ NZ } & -1.4347 & 1.9374 & -1.6887 \\
\hline & $(-1.5518)$ & (0.9847) & $(-0.9533)$ \\
\hline \multirow[t]{2}{*}{ NOR } & 0.2158 & -0.6469 & 0.4609 \\
\hline & (1.4739) & $(-1.6926)$ & (1.1768) \\
\hline \multirow[t]{2}{*}{ POR } & -1.9831 & 2.8823 & 0.6659 \\
\hline & $(-1.5098)$ & (1.1312) & $(0.4758)$ \\
\hline \multirow[t]{2}{*}{ ESP } & -0.0450 & -0.1726 & 0.3860 \\
\hline & $(-0.7440)$ & $(-0.9924)$ & (1.9835) \\
\hline \multirow[t]{2}{*}{ SWE } & 0.0656 & -0.0068 & 0.0682 \\
\hline & $(0.9987)$ & $(-0.0941)$ & (1.0195) \\
\hline \multirow[t]{2}{*}{$\mathrm{CH}$} & -0.0175 & 0.2712 & 0.1820 \\
\hline & $(-0.2239)$ & (1.3374) & (1.5014) \\
\hline \multirow[t]{2}{*}{ UK } & -0.0025 & -0.0317 & -0.0048 \\
\hline & $(-0.0859)$ & $(-0.5810)$ & $(-0.0695)$ \\
\hline
\end{tabular}


Notes: This table presents results from regressions of the form

$$
\Delta s_{t+1}^{i}=\mu+\beta_{\Delta c} \Delta c_{t+1}+\beta_{\Delta c, i} \Delta c_{t+1}\left(i_{t}^{i}-i_{t}\right)+\varepsilon_{t+1}
$$

with $\Delta s_{t+1}^{i}$ the U.S. dollar exchange rate change of country $i, \Delta c_{t+1} \log$ U.S. consumption growth, $i_{t}^{i}-i_{t}$ the interest differential of country $i$ relative to the U.S. 
Table7: Risk price and GMM estimates (scaled currency returns)

\begin{tabular}{cccc}
\hline \hline & \multicolumn{4}{c}{ Panel A: Fama-MacBeth } & $R^{2}$ \\
\hline & $\lambda_{0}$ & $\lambda_{\Delta c}$ & 0.44 \\
CCAPM & -2.63 & 0.54 & \\
& $(-4.13)$ & $(3.16)$ & \\
\hline \multicolumn{4}{c}{ Panel B: GMM } \\
CCAPM & $b_{\Delta c}$ & J-Test (p-value)
\end{tabular}

Notes: Notes: Panel A of this table gives the risk prices from cross-sectional Fama-MacBeth CCAPM regressions of the form

$$
r_{t}^{e, i}=\lambda_{0}+\lambda_{C} \beta_{\Delta c}^{i}+\varepsilon_{t}^{i}, \forall t
$$

of individual currency returns scaled with the respective stock return differential relative to the U.S. Betas are obtained from time-series regressions on consumption growth. As the betas are generated regressors, t-statistics that are corrected for this errors-in-variables issue (Shanken, 1992) are reported inparenthesis. $\mathrm{R}^{2}$ denotes the adjusted cross-sectional $\mathrm{R}^{2}$. The sample period is from first quarter 1974 to first quarter 2005.

Panel B of this table reports estimates of the coefficient of relative risk aversion from a twostage GMM estimation of linear versions of the CCAPM. The stochastic discount factor is specified as $m_{t+1}=1-b_{\Delta c} \Delta \log c_{t+1}$

I use the identity matrix in the first stage and the optimal weighting matrix in the second stage applying a lag length of 12 . The qualitative results are not influenced by the choice of lag length.. The J-Test is a $\chi^{2}$-test of the null that all pricing errors are jointly zero with degrees of freedom equal to number of moments less number of parameters.

are jointly zero with degrees of freedom equal to number of moments less number of parameters. 


\section{Figures}

Figure 1: Fit of the CCAPM (returns on currency portfolios)

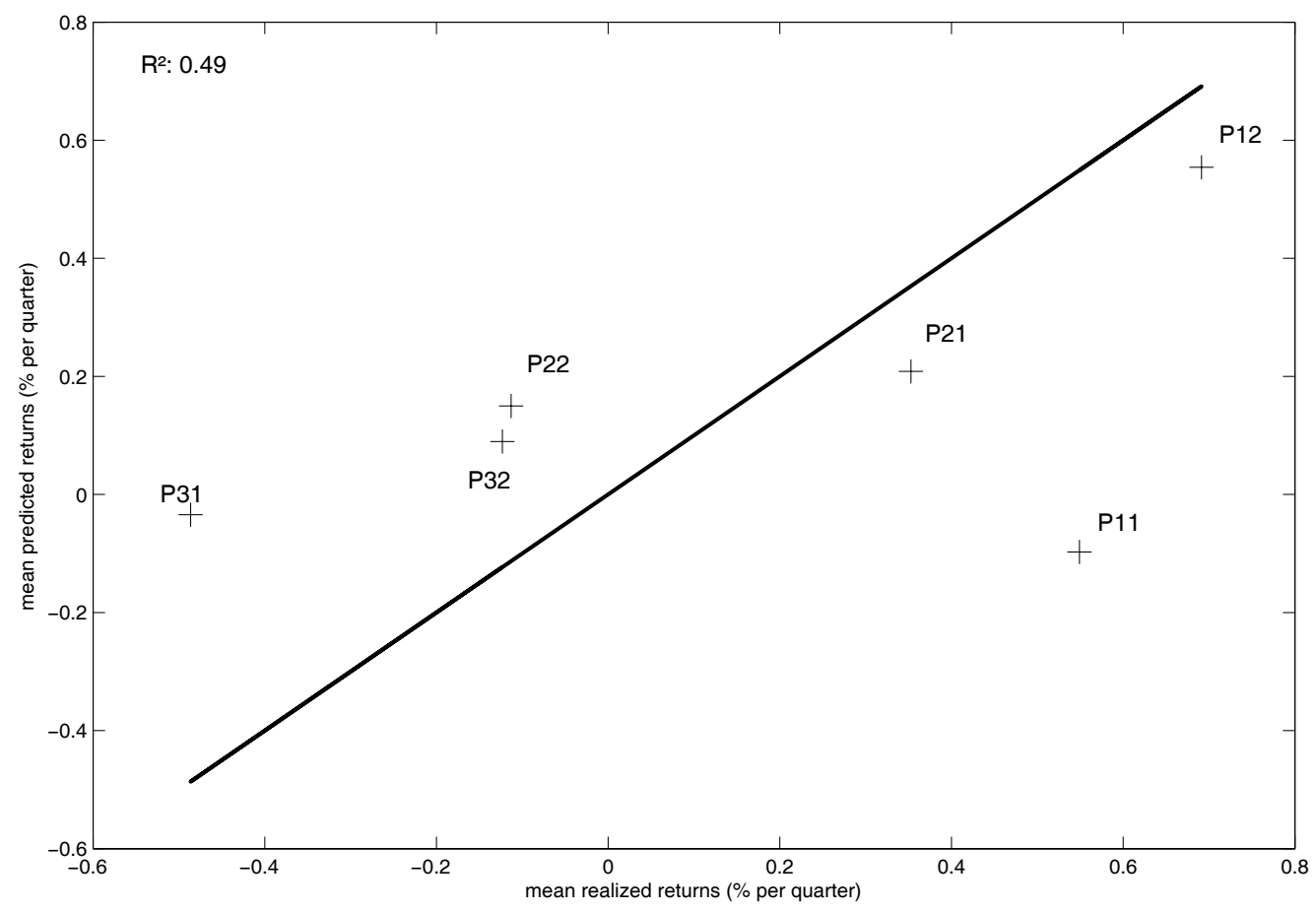

Figure 2: Mean returns on currency portfolios vs. consumption growth betas

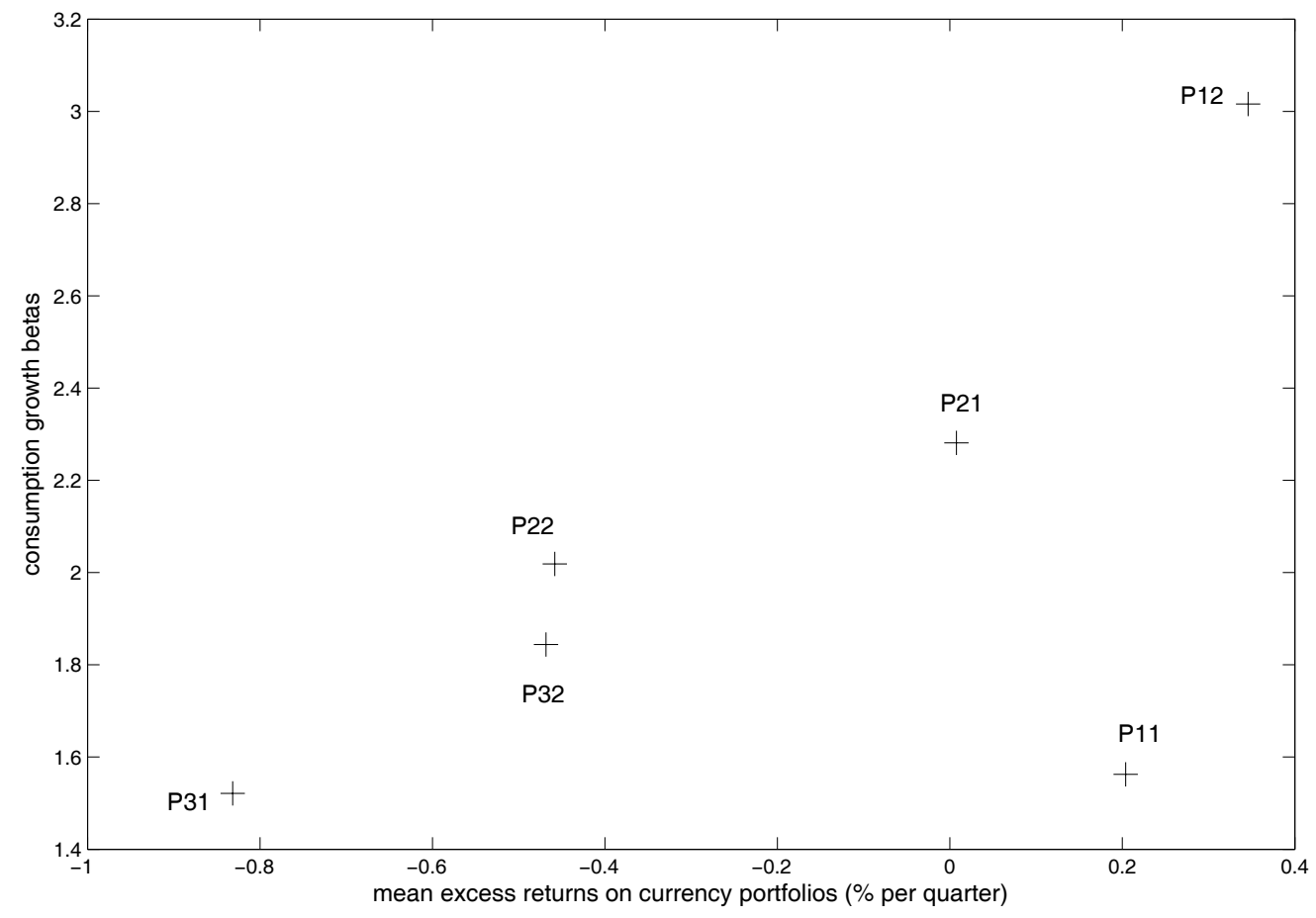


Figure 3: Mean currency returns and consumption growth betas conditional on time variation in stock return differentials
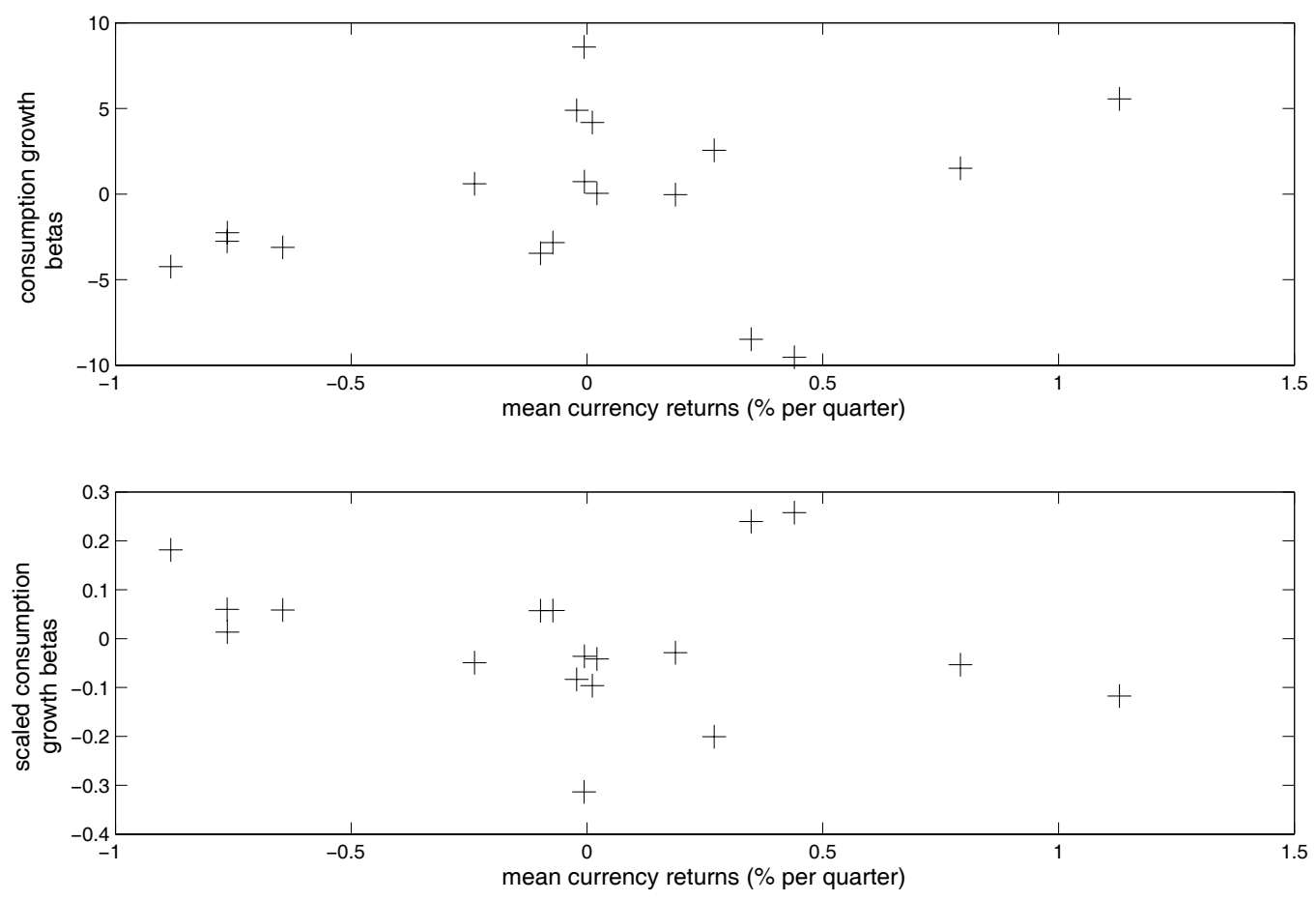
Figure 4: Mean currency returns and consumption growth betas conditional on time variation in interest rate differentials
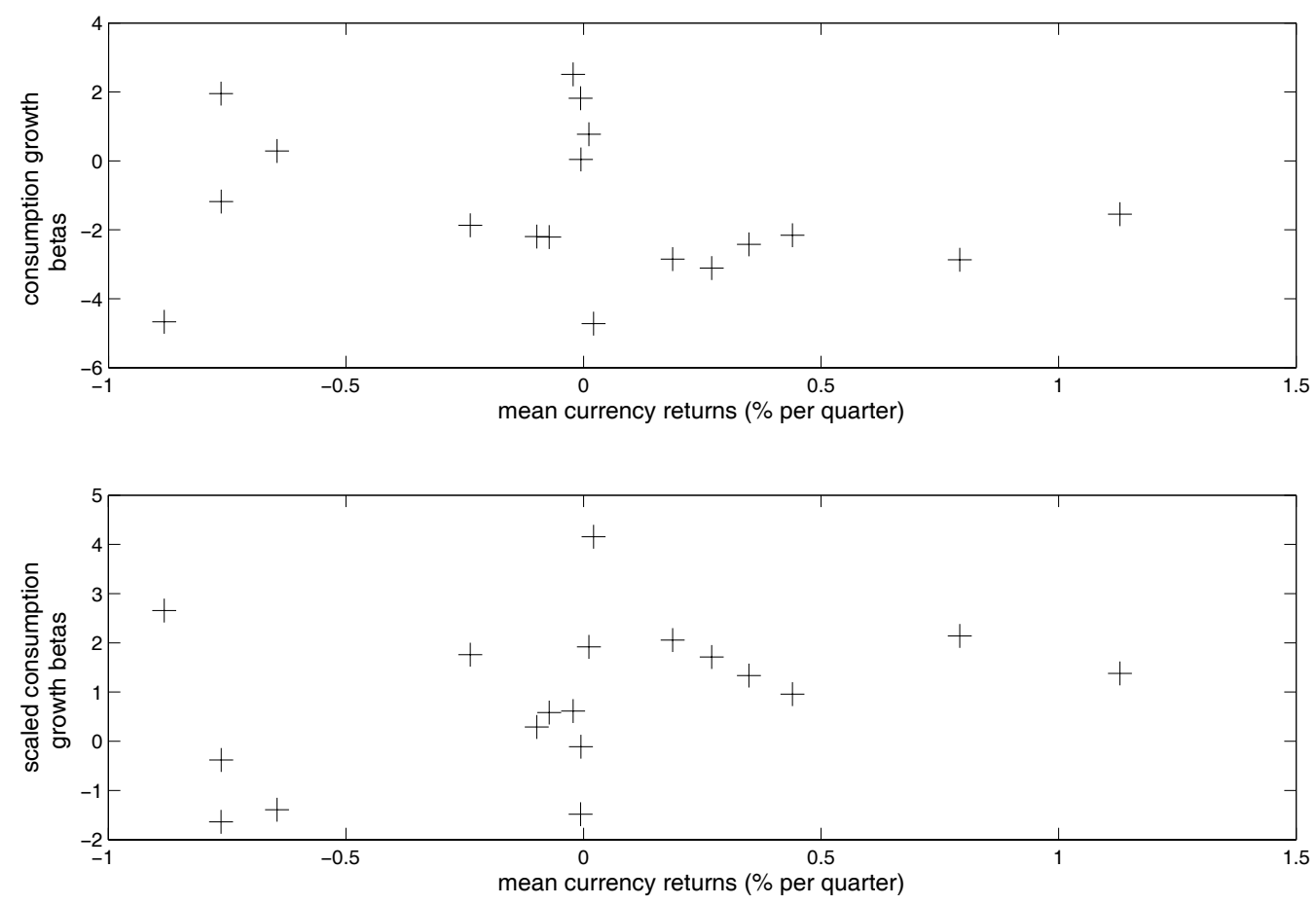

Figure 5: Fit of the CCAPM for scaled foreign currency returns

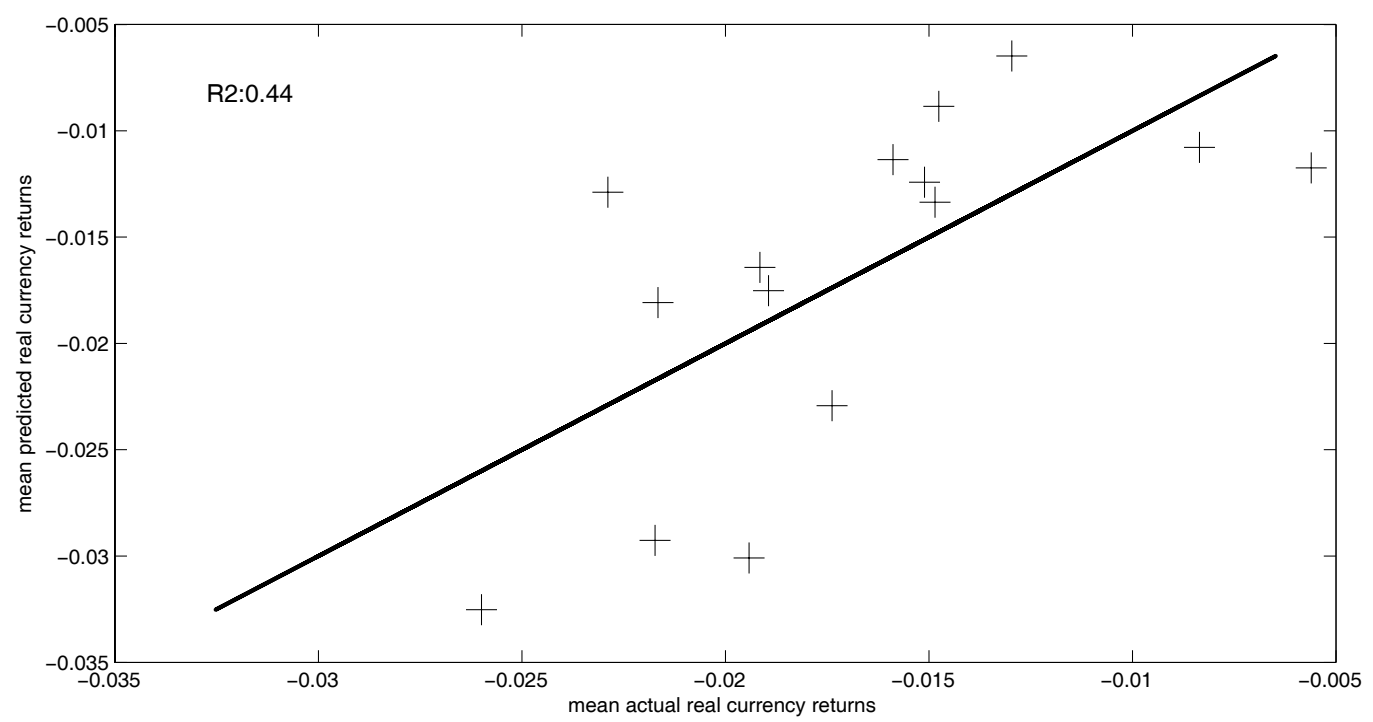


Figure 6: Scaled foreign currency returns and consumption growth betas

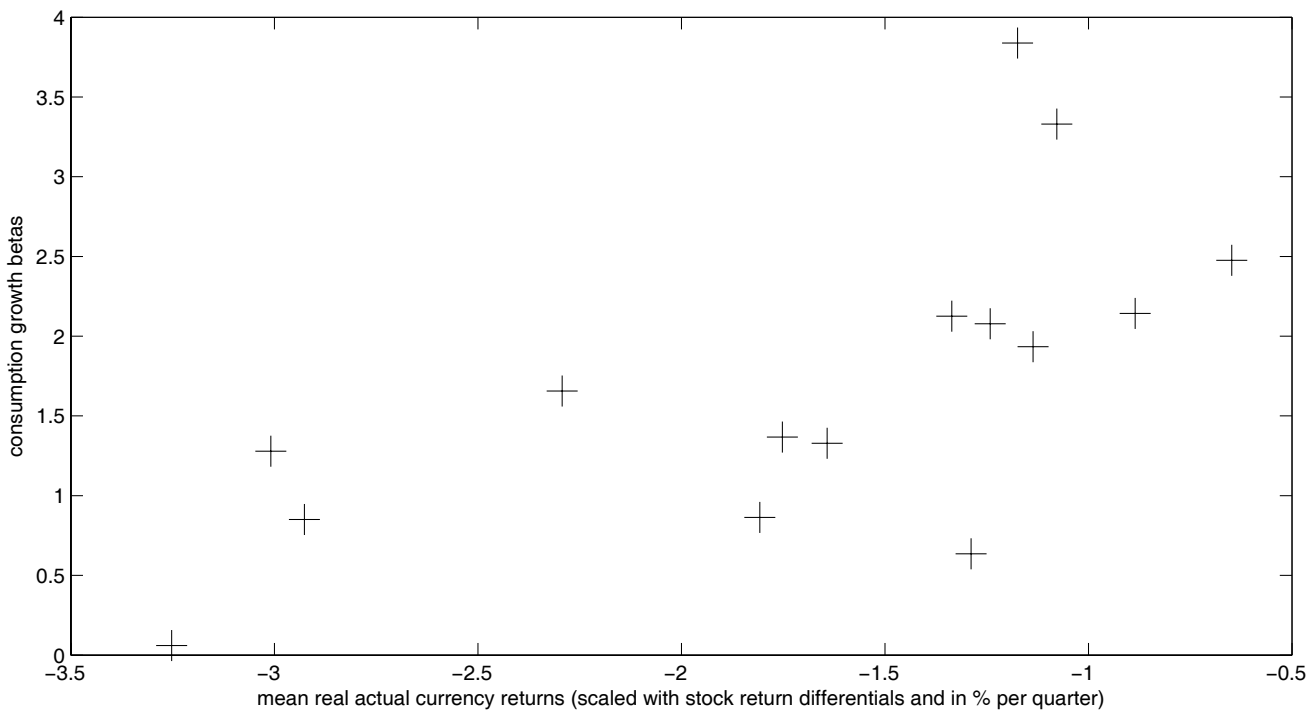

